\title{
Analisis dan Perancangan Sistem Pengelola Data Menuju Implementasi Data Warehouse Untuk Mendukung Administrasi E-Procurement
}

\author{
I Gusti Ngurah Adhy Pradhana $^{1}$, Ida Ayu Dwi Giriantari ${ }^{2}$, I Made Sudarma ${ }^{3}$
}

\begin{abstract}
ULP (Procurement Unit) Udayana University is an institution that organizes the procurement process of Goods/ Services within Udayana University, that includes procurement planning, procurement implementation and reporting of the procurement. This study resulted in a data warehouse application that can summarize, integrate historical data and present information from various dimensions that assist stakeholders in analyzing their policy strategies. Information generated from data warehouse will make it easy for reporting of Goods/Services Procurement at Udayana University to summarize the data and also enable stakeholders to view their data from various dimensions. Data warehouse is designed to facilitate the organization in obtaining information for further analysis and can also be a reference in developing other applications. Data warehouse modeling that has built names SIGAP, which has proven to successfully improve the performance of government goods procurement information system in Udayana University. The improvement is the speed and accurity in finding procurement report for stakeholders or other user. This is measured from the feasibility test of the system which showed in satisfaction score for efficiency is 4.31 out of 5.00. This shows that stakeholders or user can get procurement reports faster using SIGAP application than usual method.
\end{abstract}

Intisari- ULP (Unit Layanan Pengadaan) Universitas Udayana merupakan sebuah lembaga yang menyelenggarakan proses pengadaan Barang/Jasa di lingkungan Universitas Udayana, dimana kegiatan itu meliputi perencanaan, pelaksanaan pengadaan dan pelaporan pengadaan barang/jasa itu sendiri. Penelitian ini menghasilkan suatu aplikasi data warehouse yang dapat merangkum, mengintegrasikan data historis dan menyajikan informasi dari berbagai dimensi yang membantu pemangku kepentingan dalam melakukan analisis terhadap strategi kebijakannya. Informasi yang dihasilkan dari data warehouse akan memberikan kemudahan bagi pelaporan Pengadaan Barang/ Jasa di lingkungan Universitas Udayana dalam merangkum datanya dan juga memudahkan pemangku kepentingan untuk melihat datanya dari berbagai dimensi. Dari perancangan data warehouse tersebut, dapat mempermudah organisasi dalam memperoleh informasi untuk analisis lebih lanjut dan juga dapat menjadi acuan dalam mengembangkan aplikasi lainnya. Pemodelan data warehouse yang dalam hal ini dinamakan aplikasi SIGAP,

berdasarkan penelitian yang dilakukan berhasil

${ }^{I}$ Mahasiswa, Magister Teknik Elektro Universitas Udayana Gedung Pascasarjana Universitas Udayana Jl. PB Sudirman Denpasar-Bali 80232 (tlp/fax: 0361-239599; email:igustingurahadhypradhana@gmail.com)

${ }^{2}$ Dosen, Magister Teknik Elektro Universitas Udayana Gedung Pascasarjana Universitas Udayana Jl. PB Sudirman Denpasar-Bali 80232 (tlp/fax: 0361-239599;email:dayu.giriantari@unud.ac.id)

${ }^{3}$ Dosen, Magister Teknik Elektro Universitas Udayana Gedung Pascasarjana Universitas Udayana Jl. PB Sudirman Denpasar-Bali 80232 (tlp/fax:0361-239599;email: msudarma@unud.ac.id)

I.G.N Adhy Pradhana: Analisis dan Perancangan Sistem... meningkatkan kinerja sistem informasi pengadaan Barang/Jasa pemerintah di lingkungan Universitas Udayana. Peningkatan yang dimaksud dalam hal kecepatan pemangku kepentingan/pihak terkait dalam menemukan laporan pengadaan dan keakuratan datandalam laporan. Hal ini diukur dari pengujian kelayakan sistem yang dikembangkan, yaitu berdasarkan hasil usability test dari setiap pertanyaan terhadap aspek efficiency, didapatkan nilai kepuasan rata-rata yang mencakup aspek efficiency sebesar 4,31. Nilai ini dapat diartikan bahwa pemangku kepentingan mendapatkan laporan pengadaan lebih cepat setelah menggunakan aplikasi SIGAP.

Kata Kunci- Data Warehouse, Pengadaan Barang/ Jasa

\section{PENDAHULUAN}

Tuntutan penyelenggaraan pengadaan secara efektif dan efisien mengharuskan LKPP untuk terus mengembangkan layanan yang sesuai dengan kondisi dewasa ini.

Mekanisme pasar dan didukung oleh teknologi informasi yang mutakhir memunculkan skema pengadaan yang lebih praktis [1]. Akibat perkembangan yang sangat pesat dibidang informasi tersebut, terjadilah perubahan-perubahan tata cara pelaksanaan suatu pengadaan, dari cara-cara konvensional diperbaharui menjadi Sistem Pengadaan Secara Elektronik (SPSE) yang memungkinkan melakukan proses pelelangan melalui media elektronik.

SPSE adalah aplikasi e-procurement yang dikembangkan oleh LKPP dijalankan oleh LPSE di instansi pemerintah seluruh Indonesia. Dalam perkembangannya SPSE yang digunakan dapat menunjang efisiensi nasional karena tidak memerlukan biaya lisensi. SPSE yang dihasilkan oleh LKPP bersama dengan Lembaga Sandi Negara (lemsaneg) dalam hal enkripsi dokumen dan Badan Pengawas Keuangan dan Pembangunan (BPKP) untuk subsistem audit [1].

Tujuan dibentuknya LPSE di seluruh instansi pemerintah (K/L/D/I) baik itu kementerian/ lembaga/ satuan kerja perangkat daerah/ institusi lainnya yaitu mengatur sistem pelayanan pengadaan barang/jasa secara elektronik serta memfasilitasi ULP, pejabat pengadan dalam melakukan pengadaan barang/ jasa secara elektronik. ULP, pejabat pengadaan pada kementerian/ lembaga/ perguruan tinggi/ BUMN yang tidak membentuk LPSE dapat menggunakan fasilitas LPSE terdekat dari tempat kedudukannya untuk melakukan pengadaan secara elektronik. Disamping Tugas pokok LPSE dalam melayani ULP, pejabat pengadaan dalam melakukan pengadaan barang/ jasa secara elektronik, LPSE juga memberikan layanan registrasi penyedia barang/ jasa di wilayah kerja LPSE tersebut berdiri.

Payung hukum pembentukan LPSE adalah pasal 111 PERPRES nomor 54 tahun 2010 tentang pengadaan barang/ jasa pemerintah yang petunjuk teknis operasionalnya diatur p-ISSN:1693 - 2951; e-ISSN: 2503-2372 
oleh Perka LKPP nomor 2 tahun 2010 tentang layanan pengadaan secara elektronik. Dalam pelaksanaan sistem pelayanan pengadaan barang/ jasa secara elektronik LPSE harus mengacu pada UU nomor 11 tahun 2008 tentang informasi dan transaksi elektronik.

Sejumlah fitur dikembangkan oleh sistem pengadaan secara elektronik dengan menu yang populier e-tendering dengan rujukan operasionalnya mengacu pada Perka (peraturan kepala) LKPP nomor 1 tahun 2011 tentang tata cara e-tendering. LKPP juga menyediakan katalog elektronik (e-catalogue) yaitu sistem informasi elektronik berisikan daftar, jenis, spesifikasi teknis dan harga barang dari berbagai penyedia barang/ jasa pemerintah, proses audit secara online (e-audit), serta tata cara pembelian barang/jasa melalui katalog elektronik (e-purchasing) [2].

\section{KAJIAN PUSTAKA}

OLAP merupakan tools dalam mengakses informasi pada data warehouse. Pada OLAP dimungkinkan data warehouse digunakan secara efektif untuk proses online analysis, memberikan respon yang cepat bagi analytical queries yang kompleks [8]. Multidimensional data model dan teknik agregasi data yang terdapat pada OLAP dapat mengatur dan membuat kesimpulan dari data dalam jumlah besar, sehingga dapat dievaluasi secara cepat dengan menggunakan online analysis dan graphical tool. OLAP memfasilitasi kecepatan dan fleksibilitas dalam melakukan support analisis secara real time.

Dalam pengolahan data warehouse telah banyak penelitian sebelumnya menguraikan penerapan fuzzy multi attribute decision making seperti: C.B Chen dalam An Efficient Approach to Solving Fuzzy MADM memaparkan apabilan terjadi suatu permasalahan. Data-data atau informasi yang diberikan, baik oleh pengambil keputusan maupun data mengenai atribut suatu alternatif yang tidak dapat disajikan dengan lengkap, mengandung ketidakpastian atau ketidakkonsistenan, maka metode MCMD biasa tidak dapat dipergunakan menyelesaikan permasalahan tersebut [3].

Oleh karena itu, dalam mengatasi masalah tersebut, digunakanlah metode fuzzy MCDM, yang terbukti memiliki kinerja yang sangat baik. Kusumadewi memaparkan tentang Fuzzy Multi Attribute Decision Making (MADM) dan menjabarkan tentang metode pengembangan lain guna menyelesaikan masalah MDAM, melalui pendekatan subyektif, obyektif dan integrasi antara pendekatan subyektif dan obyektif [4]. Penelitian Fuzzy Multi Criteria Decision Making (FMCDM) dalam penentuan lokasi pemancar televisi.

GS Liang memaparkan mengenai Multi Criteria Decision Making ditinjau dari teori yang ideal dan tidak ideal [5]. Pada tulisan Kusumadewi menjabarkan penyelesaian masalah fuzzy MADM, dimana penyelesaian masalah fuzzy MADM dengan menggunakan MADM biasa seperti Simple Additive Weighting (SAW), Weighted Product (WP), atauTechnique for Order Preference by Similarity to Ideal Solution (TOPSIS), disertai contoh-contoh kasus yang dapat terselesaikan, pemrograman dalam menyelesaikan MADM dengan pendekatan Subyektif Obyektif menggunakan Software Matlab [6].

\section{A. Algoritma FMADM}

Algoritma FMADM diperoleh dengan cara:

1. Nilai diperoleh dari nilai crisp: $\mathrm{i}=1,2, \ldots \mathrm{m}$ dan $\mathrm{j}=1,2 \ldots \mathrm{n}$, melalui penilaian dari setiap alternatif (Ai) pada tiap kriteria $(\mathrm{Cj})$ yang ditentukan.

2. Nilai crisp tersebut menentukan bobot (W).

3. Menormalisasi matriks dengan menghitung nilai rating kinerja ternormalisasi (rij) alternatif $\mathrm{Ai}$ untuk tiap $\mathrm{Cj}$ didasarkan oleh persamaan yang disesuaikan dengan jenis atribut (atribut keuntungan/benefit=MAKSIMUM atau atribut biaya/ cost=MINIMUM. Untuk mencari atribut keuntungan, membagi nilai crisp (Xij) tiap kolom dengan nilai crisp MAX (MAX Xij) tiap kolom, sedangkan untuk atribut biaya, nilai crisp MIN (MIN Xij) tiap kolom atribut dibagi dengan nilai crisp (Xij) tiap kolom.

4. Dilakukan proses perangkingan dengan cara nilai bobot (W) dikalikan matriks ternormalisasi (R).

5. Menetapkan nilai preferensi untuk tiap alternatif (Vi) dengan cara menambahkan hasil kali matriks ternormalisasi (R) dengan bobot (W), jika diperoleh $\mathrm{Vi}$ yang lebih besar, kemungkinan besar Ai yang terpilih [4].

Dalam penelitian ini diterapkan FMADM dengan metode SAW ditunjukan dalam Gambar 1: dengan tahapan sebagai berikut:

1. Penentuan kriteria-kriteria yang akan dijadikan acuan dalam pengambilan keputusan, yaitu $\mathrm{Ci}$.

2. Setiap kriteria akan dihitung rating kecocokannya.

3. Dibentuk matriks keputusan berdasarkan kriteria (Ci), menormalisasi matriks didasarkan atas persamaan disesuaikan dengan jenis atribut (keuntungan atau biaya) sampai diperoleh matriks ternormalisasi (R).

4. Diperoleh hasil proses perangkingan yaitu, suatu nilai penjumlahan terhadap perkalian matriks ternormalisasi $\mathrm{R}$ terhadap vektor bobot sehingga diperoleh nilai terbesar yang diharapkan menjadi alternatif terbaik (Ai) [7].

\section{ANALISIS DAN PERANCANGAN SISTEM}

Dalam penelitian ini dilakukan analisa data vendor saat evaluasi teknis pengadaan barang/ jasa pemerintah, data ini akan diolah dengan metode Simple Additive Weighting. Analisa yang diperlukan adalah kesesuaian data dalam komponen evaluasi yang dipersyaratkan oleh pokja ULP Universitas Udayana dengan ketersediaan dokumen yang ditawarkan oleh vendor. Skala pembanding mencari kecocokan rating alternatif yang ada, proses berikutnya adalah normalisasi matriks keputusan (X).

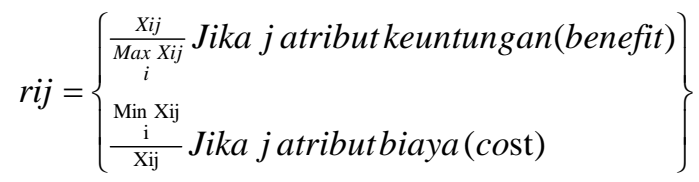


rij adalah rating kinerja ternormalisasi dari alternatif $\mathrm{Ai}$ pada atribut $\mathrm{Cj}$ : $\mathrm{i}=1,2, \ldots, \mathrm{m}$ dan $\mathrm{j}=1,2, \ldots, \mathrm{n}$.

Nilai preferensi untuk setiap alternatif (Vi) dijabarkan sebagai:

$$
V i=\sum_{j=1}^{n} W j r i j
$$

Nilai Vi yang lebih besar mengindikasikan bahwa alternatif Ai lebih terpilih

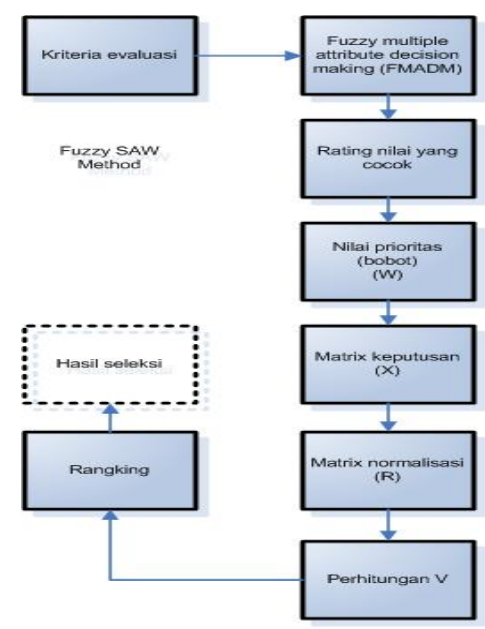

Gambar 1: Skema Metode SAW

Nilai-nilai terhadap indikator yang dapat diterjemahkan kedalam suatu nilai dalam hal ini proses evaluasi dari kelompok kerja ULP (Pokja ULP) seperti Daftar Usulan Spesifikasi Teknis Barang, Jadwal Pengiriman Barang, Jadwal Waktu Pelaksanaan, Identitas (jenis, tipe, merk) yang ditawarkan tercantum secara lengkap dan jelas, surat dukungan menjelaskan ketersediaan barang dari distributor bermaterai $6000,-$.

Setiap indikator diatas ditetapkan sebagai kriteria yang dijadikan sebagai faktor untuk menentukan kelulusan dari penawaran tiap-tiap vendor dan himpunan fuzzynya adalah sesuai, tidak sesuai, tidak ada. Selanjutnya himpunan berikut diperlakukan sebagai input kedalam sistem FMADM (dalam hal ini disebut sebagai (Ci).

Penelitian ini mempunyai output laporan yang dibutuhkan sesuai dengan Pasal 11 Perpres Nomor 54 Tahun 2010, menyatakan tugas pokok dan kewenangan PPK adalah: melaporkan kemajuan pekerjaan termasuk penyerapan anggaran pelaksanaan pekerjaan kepada PA/KPA setiap triwulan termasuk hambatannya.

Sistem informasi terintegrasi (SIGAP) yang dibangun akan mengintegrasikan proses pengadaan barang/ jasa di lingkungan Universitas Udayana dengan mempergunakan laporan dan data terkait proses pengadaan yang masih bersifat fisik/ konvensional ditransformasikan kedalam bentuk format laporan sesuai dengan kebutuhan pemeriksaan dari lembaga terkait seperti BPK, KPK, lembaga lain serta pemangku kepentingan terkait lainnya.

Input untuk melakukan proses pengambilan keputusan dari tiap alternatif ini diselesaikan menggunakan data evaluasi dari panitia/pokja pengadaan barang/ jasa semacam berita acara (BA) seperti ditunjukan dalam Tabel 1. Kriteria yang dibutuhkan adalah sebagai berikut:

1. Daftar Usulan Spesifikasi Teknis

2. Jadwal Pengiriman Barang

3. Jadwal Waktu Pelaksanaan

4. Identitas (jenis,tipe,merk) yang ditawarkan tercantum secara lengkap dan jelas.

5. Surat dukungan menjelaskan ketersediaan barang dari distributor bermaterai 6000,-. 
TABEL I

EVALUASI TEKNIS POKJA (KELOMPOK KERJA) ULP UNIVERSITAS UDAYANA

\begin{tabular}{|c|c|c|c|c|c|c|c|}
\hline No & Nama Perusahaan & $\begin{array}{c}\text { Daftar Usulan } \\
\text { Spesifikasi Teknis } \\
\text { Barang }\end{array}$ & $\begin{array}{c}\text { Jadwal Pengiriman } \\
\text { Barang }\end{array}$ & $\begin{array}{c}\text { Jadwal Waktu } \\
\text { Pelaksanaan }\end{array}$ & $\begin{array}{c}\text { Identitas } \\
\text { (jenis,tipe,merk) yang } \\
\text { ditawarkan tercantum } \\
\text { secara lengkap dan } \\
\text { jelas } \\
\end{array}$ & $\begin{array}{c}\text { Surat dukungan } \\
\text { menjelaskan } \\
\text { ketersediaan barang } \\
\text { dari distributor } \\
\text { bermaterai } 6000,-\end{array}$ & Klasifikasi \\
\hline 1 & CV. Borneo Sukses Abadi & ada (sesuai) & 15 hari kerja & 30 hari kerja & ada (sesuai) & ada (sesuai) & lulus \\
\hline 2 & CV. Dwi Karya Abadi & ada (sesuai) & 16 hari kerja & 30 hari kerja & ada (sesuai) & ada (sesuai) & tidak lulus \\
\hline 3 & CV. Sarana Ilmu & ada (sesuai) & 15 hari kerja & 30 hari kerja & ada (tidak sesuai) & ada (sesuai) & tidak lulus \\
\hline 4 & UD. Persada Pratama & ada (sesuai) & 15 hari kerja & 30 hari kerja & ada (sesuai) & ada (sesuai) & lulus \\
\hline 5 & CV. Pribadi & ada (sesuai) & 15 hari kerja & 30 hari kerja & ada (sesuai) & tidak ada & tidak lulus \\
\hline 6 & UD. Ananda & ada (sesuai) & 15 hari kerja & 31 hari kerja & ada (sesuai) & tidak ada & tidak lulus \\
\hline
\end{tabular}

\section{A. Analisa Kebutuhan Output}

Penelitian ini menghasilkan suatu alternatif yang memiliki nilai tertinggi dibandingkan dengan alternatif yang lain.

Penelitian ini mengambil suatu nilai keluaran (output) berdasarkan nilai tertinggi, dan diharapkan lebih dari satu keluaran bernilai sama. Pada penelitian ini alternatif yang akan diperlihatkan dimulai dari alternatif tertinggi hingga alternatif terendah. Pada tulisan ini alternatif yang digunakan sebagai contoh ialah perangkingan evaluasi teknis. Dalam penelitian ini ada kriteria dan bobot yang dipakai untuk menentukan proses penyeleksian dari evaluasi teknis yang lulus dan tidak lulus. Tabel 2 menunjukan beberapa kriteria yang dipakai:

TABEL 2

KRITERIA YANG DIGUNAKAN

\begin{tabular}{|c|l|}
\hline Kriteria & \multicolumn{1}{|c|}{ Keterangan } \\
\hline $\mathrm{C} 1$ & Daftar Usulan Spesifikasi Teknis Barang \\
\hline $\mathrm{C} 2$ & Jadwal Pengiriman Barang \\
\hline $\mathrm{C} 3$ & Jadwal Waktu Pelaksanaan \\
\hline $\mathrm{C} 4$ & $\begin{array}{l}\text { Identitas (jenis,tipe,merk) yang ditawarkan tercantum secara } \\
\text { lengkap dan jelas. }\end{array}$ \\
\hline C5 & $\begin{array}{l}\text { Surat dukungan menjelaskan ketersediaan barang dari } \\
\text { distributor bermaterai 6000,- }\end{array}$ \\
\hline
\end{tabular}

Berdasarkan bobot tersebut, dibuatlah variabel-variabelnya. Dimana dari suatu variabel tersebut akan dikonversi kedalam bilangan fuzzy. Tabel 3 berikut adalah bilangan fuzzy dari bobot.
TABEL 3

BOBOT YANG DIGUNAKAN

\begin{tabular}{|c|c|}
\hline Bilangan Fuzzy & Nilai \\
\hline Tidak ada & 0.3 \\
\hline Tidak sesuai & 0.6 \\
\hline sesuai & 0.9 \\
\hline
\end{tabular}

Berdasarkan proses evaluasi dari pokja dibuatlah matriks keputusan X seperti pada Tabel 4.

TABEL 4

KRITERIA DAN ALTERNATIF DARI EVALUASI TEKNIS PENGADAAN BARANG/JASA

\begin{tabular}{|c|c|c|c|c|c|}
\hline \multirow{2}{*}{ Alternatif } & \multicolumn{5}{|c|}{ Kriteria } \\
\cline { 2 - 6 } & $\mathrm{C} 1$ & $\mathrm{C} 2$ & $\mathrm{C} 3$ & $\mathrm{C} 4$ & $\mathrm{C} 5$ \\
\hline A1 & 0.9 & 0.9 & 0.9 & 0.9 & 0.9 \\
\hline A2 & 0.9 & 0.6 & 0.9 & 0.9 & 0.9 \\
\hline A3 & 0.9 & 0.9 & 0.9 & 0.6 & 0.9 \\
\hline A4 & 0.9 & 0.9 & 0.9 & 0.9 & 0.9 \\
\hline A5 & 0.9 & 0.9 & 0.9 & 0.9 & 0.6 \\
\hline A6 & 0.9 & 0.9 & 0.6 & 0.9 & 0.6 \\
\hline
\end{tabular}




$$
\begin{gathered}
X=\left[\begin{array}{ccccc}
0.9 & 0.9 & 0.9 & 0.9 & 0.9 \\
0.9 & 0.6 & 0.9 & 0.9 & 0.9 \\
0.9 & 0.9 & 0.9 & 0.6 & 0.9 \\
0.9 & 0.9 & 0.9 & 0.9 & 0.9 \\
0.9 & 0.9 & 0.9 & 0.9 & 0.6 \\
0.9 & 0.9 & 0.6 & 0.9 & 0.6
\end{array}\right] \\
r i j=\frac{X_{i j}}{\operatorname{Max} X i j} \\
r 11=\frac{{ }^{M}\{0.9 ; 0.9 ; 0.9 ; 0.9 ; 0.9 ; 0.9\}}{\operatorname{Max}\{0}
\end{gathered}
$$

Hasil normalisasi matriks diperoleh seperti ditunjukan dalam Tabel 5 .

TABEL 5

HASIL NORMALISASI MATRIKS

\begin{tabular}{|c|c|c|c|c|}
\hline 1 & 1 & 1 & 1 & 1 \\
\hline 1 & 0.67 & 1 & 1 & 1 \\
\hline 1 & 1 & 1 & 0.67 & 1 \\
\hline 1 & 1 & 1 & 1 & 1 \\
\hline 1 & 1 & 1 & 1 & 0.67 \\
\hline 1 & 1 & 0.67 & 1 & 0.67 \\
\hline
\end{tabular}

Terdapat tiga pendekatan untuk menentukan bobot suatu atribut yaitu pendekatan subyektif, obyektif dan integrasi antara subyektif dan obyektif. Untuk pendekatan subyektif, bobot ditentukan berdasarkan subyektifitas para pengambil keputusan, sehingga beberapa faktor dalam memberi peringkat alternatif dapat ditentukan secara mandiri. Sedangkan pendekatan obyektif, bobot dihitung secara matematis dengan mengabaikan subyektifitas para pengambil keputusan [10], kemudian ditentukan bobot kepentingan seperti Tabel 6:

TABEL 6

BOBOT KEPENTINGAN

\begin{tabular}{|l|c|}
\hline \multicolumn{1}{|c|}{ Bilangan Fuzzy } & Nilai \\
\hline Tidak ada kepentingan & 1 \\
\hline Berkepentingan & 2 \\
\hline Sangat berkepentingan & 3 \\
\hline
\end{tabular}

$\mathrm{W}=$ Tidak ada kepentingan (1), kemudian dimasukan dalam persamaan:

$$
V i=\sum_{j=1}^{n} W j \quad r i j
$$

Dari hasil kalkulasi diatas didapatlah nilai dari setiap alternatif, ditampilkan pada Tabel 7.

TABEL 7

PERANGKINGAN NILAI HASIL NORMALISASI MATRIKS

\begin{tabular}{|c|c|c|}
\hline Rangking & Alternatif & Nilai \\
\hline 1 & A1 & 5 \\
\hline 2 & A2 & 4.67 \\
\hline 3 & A3 & 4.67 \\
\hline 4 & A4 & 5 \\
\hline 5 & A5 & 4.67 \\
\hline 6 & A6 & 4.33 \\
\hline
\end{tabular}

Berdasarkan hasil perhitungan diatas diperoleh nilai terbesar adalah 5. Dua perusahaan yang memperoleh nilai 5 dalam perhitungan evaluasi teknis dari pengadaan barang/ jasa jasa dinyatakan lulus.

\section{PENGUJIAN SISTEM}

Pada Penelitian ini, dilakukan pengujian sistem menggunakan:

1. Metode Equivalence Partitioning yaitu dengan membagi data input yaitu spesifikasi modul menjadi dua kelas data yaitu data valid dan invalid [9]. Data valid merupakan data yang didapat dari spesifikasi modul valid dan data invalid merupakan data yang didapat dari spesifikasi modul invalid. Spesifikasi modul valid yang digunakan adalah spesifikasi modul Daftar, Login, Manage Data, Entry Data dan Print Data. Sedangkan spesifikasi modul invalid yang digunakan adalah spesifikasi modul Daftar dan Login.

2. Pengukuran Usability dengan Use Questionnaire oleh Jacob Nielsen berpendapat, usability merupakan suatu atribut yang digunakan untuk mengukur kemudahan penggunaan suatu antar muka (interface). Pengertian "usability" lebih didefinisikan untuk suatu metode peningkatan proses desain. Usability diukur dengan lima kriteria, yaitu: learnability, efficiency, memorability, errors, dan satisfaction

Tabel 8 menunjukan hasil pengujian fungsionalitas dan Equivalence Partitioning. 
TABEL 8

PERSENTASE HASIL PENGUJIAN (UJI FUNGSIONALITAS) (EQUIVALENCE PARTITIONING)

\begin{tabular}{|c|c|c|c|c|c|}
\hline \multirow{4}{*}{$\begin{array}{c}\text { Spesifi } \\
\text { kasi }\end{array}$} & \multirow{4}{*}{ Modul } & \multicolumn{4}{|c|}{ Hasil Pengujian } \\
\cline { 3 - 6 } & & Pass & Fail & $\begin{array}{c}\text { Persentase } \\
\text { Jumlah } \\
\text { Eksekusi }\end{array}$ & $\begin{array}{c}\text { Hasil } \\
\text { Pengujian } \\
\text { Pass/ Jumlah } \\
\text { Pengujian }\end{array}$ \\
\hline \multirow{5}{*}{ Valid } & Daftar & 5 & 0 & 5 & $100 \%$ \\
\cline { 2 - 6 } & Login & 5 & 0 & 5 & $100 \%$ \\
\cline { 2 - 6 } & Managed Data & 5 & 0 & 5 & $100 \%$ \\
\cline { 2 - 6 } & Entry Data & 5 & 0 & 5 & $100 \%$ \\
\cline { 2 - 6 } & Print Data & 5 & 0 & 5 & $100 \%$ \\
\hline \multirow{3}{*}{ Invalid } & Daftar & 5 & 0 & 5 & $100 \%$ \\
\cline { 2 - 6 } & Login & 5 & 0 & 5 & $100 \%$ \\
\hline
\end{tabular}

Dari hasil pengujian yang didapatkan, dapat dianalisis pada Tabel 8 bahwa kasus uji yang dihasilkan oleh spesifikasi valid memiliki hasil pengujian dengan ekspektasi output yang sama yaitu Pass sedangkan pada kasus uji yang dihasilkan oleh spesifikasi invalid memiliki hasil pengujian dengan ekpektasi output yang tidak sama atau berbeda pada bagian yang telah diubah isi spesifikasinya yaitu Fail, tetapi pada bagian yang spesifikasinya tidak diubah hasil pengujian sama dengan ekspektasi output (Pass).

Berdasarkan usability testing didapatkan bahwa semua atribut yang terdapat dalam pengujian usability testing memiliki nilai kepuasan diatas 4,00 dengan kata lain hasil kepuasan user terhadap aplikasi yang ditawarkan sudah berada pada tarap memuaskan.

\section{KESIMPULAN}

Penulis telah berhasil membangun sebuah sistem pendukung keputusan dalam penentuan kelulusan penawaran dari suatu vendor dalam ruang lingkup evaluasi teknis berdasarkan kriteria-kriteria yang telah ditentukan, bilangan crisp didapat dari terjemahan bilangan fuzzy, sampai mendapatkan nilai yang bisa dilakukan proses perhitungan guna mencari alternatif terbaik. Dengan banyaknya sampel yang digunakan, meningkatkan validitas data uji, serta hasil akhir dari penelitian ini adalah sebuah nilai alternatif yang terbaik dari alternatif yang lain, serta aplikasi yang dibangun memiliki uji fungsionalitas yang baik dengan data uji input dengan hasil output memiliki hasil yang sama.

\section{UCAPAN TERIMA KASIH}

Karya ini didukung oleh ULP Universitas Udayana sebagai penyedia data dalam melakukan penelitian.

\section{REFERENSI}

[1] LKPP. "Lembaga Kebijakan Pengadaan Barang/Jasa Pemerintah." [Online]. Available: http://www.lkpp.go.id/v3/\#/read/3821, [Accessed: 03 Nopember 2015].

[2] LPSE. "Sistem Pengadaan Secara Elektronik (SPSE)- LPSE- Sistem Pengadaan Secara Elektronik (SPSE). Sekretariat Jendral Kementerian Keuangan." [Online]. Available: http: //www.setjen.kemenkeu.go.id/page/sistem-pengadaan-secara-elektronikspse. [Accessed: 03 Nopember 2015].

[3] Chen, C.B., dan Klein. "An Efficient Approach to Solving Fuzzy MADM." Fuzzy Sets and Systems vol 88, hal. 51-56, 1997.

[4] Kusumadewi, S. "Fuzzy Multi Attribut Decision Making (Fuzzy MADM)." Penerbit Graha Ilmu, Yogyakarta. 2006

[5] Liang, G.S., "Fuzzy MCDM Based on Ideal and Anti-Ideal Concept, dalam: Yeh, Chung-Hsing. 2002. A Problem-Based Selection of Multi Atribut Decision Making Methods." International Transaction in Operational Research, pp. 169-181, Blackwell Publishing. 1999

[6] Joo, H.M; dan Kang, C.S, “Application of Fuzzy Decision Making Method to the Evaluation of Spent Fuel Storage Options.” South Korea. 2004

[7] Hermawan, Julius. “Membangun Decision Support System”, Penerbit Andi, Yogyakarta. 2005

[8] William, C. Amo. “Microsoft SQL Server OLAP Developer's Guide. Foster City, CA: IDG Books Worldwide”. 2000

[9] Suri Karuniawati, Sri Widowati, Iman Lukmanul Hakim. "Implementasi Metode Cause Effect Graphing (CEG) dalam Pengujian Requirement Perangkat Lunak (Studi Kasus: Aplikasi G-College)”. e-Proceeding of Engineering: Vol.2, No.2 Agustus 2015, Page 6475. 2015

[10] Widayanti Deni, Oka Sudana and Arya Sasmita. "Analysis and Implementation Fuzzy Multi-Attribute Decision Making SAW Method for Selection of High Achieving Students in Faculty Level". IJCSI International Journal of Computer Science Issues, Vol. 10, Issue 1, No 2, January 2013. ISSN (Print): 1694-0784 | ISSN (Online): 1694-0814. www.IJCSI.org 